Literature Reviews

\title{
Coronavirus (COVID-19) Implications on the Livelihoods of the Farmers
}

\author{
${ }^{1}$ Brivery Siamabele and ${ }^{2}$ Yunike Phiri \\ ${ }^{1}$ Pan African University, Institute of Governance, Humanities and Social Sciences (PAUGHSS), Zambia \\ ${ }^{2}$ Agricultural Policy, Farm to Market Alliance-Zambia, Zambia
}

Article history

Received: 16-07-2020

Revised: 12-04-2021

Accepted: 28-04-2021

Corresponding Author: Brivery Siamabele

Pan African University, Institute of Governance, Humanities and Social Sciences (PAUGHSS)

Eamil: briverys@gmail.com

\begin{abstract}
This study aimed at reviewing the literature on Coronavirus (COVID-19) implications on the livelihoods of the farmers. Using a literature review, the paper aimed at understanding how COVID-19 has impacted the livelihoods of the farmers whose survival depends on agriculture. Driven by the following objectives; the paper reviewed firstly, lessons to be learned from the past pandemics, secondly, how COVID-19 has affected farmers' livelihoods and thirdly, the effects of COVID-19 impacts on communities. The paper argues that, with the enormous public health policies on avoiding the spread of the pandemic, the livelihoods of the farmers have largely been affected due to reduced productivities, challenges in accessing and utilizing the markets for a nutritious and food secure life is leading to increasing poverty levels. Poverty, creates vulnerabilities making farmers susceptible to crime, human trafficking, theft and rape as observed in most African countries in the COVID-19 period. Hence, the need to avoid seeing the world through western homogeneous lenses to context-specific in the fight against the spread of COVID-19.
\end{abstract}

Keywords: Agriculture Sector, Africa, Coronavirus (COVID-19), Human Trafficking, Livelihoods

\section{Introduction}

\section{Background}

Beginning the $1960 \mathrm{~s}$, a major revision in development thinking argued for a central role for agriculture as a driver of growth, especially in the early stages of industrialization (Johnston and Mellor, 1961). This view of agriculture's leading role stimulated the need for more investments in agriculture in a large part of the emerging experience in Asia and it was founded on two core contributions. The importance of the agriculture sector was equally acknowledged by scholars like (Schultz, 1964; Hayami and Ruttan, 1971) who argued that traditional agriculture can be transformed rapidly into a modern sector through the adoption of science-based technology, thereby, enhancing the sector's contribution to the economic growth. Also, economists now explicitly identified the strong growth linkages and multiplier effects of agricultural growth to the non-agricultural sectors (Byerlee et al., 2009; Mellor, 1998).

The significance of the agriculture sector in any economy dates back in history as it was considered to be a pro-poor sector in the 1970 s with the focus of bringing about equity and employment to the vulnerable members of different communities. Also, there has been growing evidence that productivity in the agricultural sector as a pro-poor enhances growth across millions of smallholders. Literature has indicated that in the 1990s, the development community explicitly recognized poverty reduction as the major objective of any development programs, scholars and development actors started to demonstrate how agriculture is connected or linked to poverty reduction (Timmer, 2002; Thirtle et al., 2003; Christiaensen and Demeny, 2007).

Agriculture has always played an essential role in the economy of every country and this is not only because the sector tends to provide food for the entire population of a country but also the sector helps to connect and interact with all the non-agriculture sectors of the economy. It is worth noting that, largely a country is believed to not only be social, political but also economically stable if the agricultural sector is stable in terms of production, market, processing and transportation. However, people in developing countries who depend on agriculture for their living are always much poorer than those who work in other sectors of the economy. and generally, those who are involved in agriculture always represents a significant 
share of the total number of poor people in the countries where they live. This then drives us to the preoccupation of this paper looking at the livelihoods of the poor farmers in these challenging moments of the COVID-19 pandemic. Driven by the following questions 'what lessons can be learnt from the various pandemics, how has COVID-19 affected the food security levels of the farmers and what effects emanate from these impacts in the communities'. It is largely, expected that the socio-economic impacts of COVID-19 will be beyond imagination in Africa where the majority of the households depend on agriculture.

As soon as the COVID-19 pandemic takes hold in Africa, many governments had begun to tighten borders, restrict gatherings and closed schools. The crisis has fundamentally changed people's lives not just with regards to public health but in terms of politics, the economy, public services and much more (Moseley, 2020). The lockdowns in preventing the spread of coronavirus have enormous impacts on food systems globally. This is because COVID-19 leads to widespread income losses, fewer consumers may be able to afford specialized or high-value products, including organic vegetables. Reductions in such purchases could further stress growers, especially if they sell directly to consumers at markets rather than through grocery stores (Poppick, 2020). Coronavirus is an interesting extreme event to food systems, as it is bordering around the social event (Poppick, 2020). It is regarded as having social event implications on food systems as it has nothing to do with weather shock or infrastructure failure or shortcoming. Other development challenges like natural disasters tend only to impact a particular area of the world, but coronavirus has had a much more pervasive effect on a social and institutional level and in other words, this virus is a different sort of disaster (World Bank, 2006a).

\section{Methodology}

This article is a review of data from secondary sources. Data from secondary sources included the published and unpublished information on how COVID-19 is altering the agricultural sector and eventually the livelihoods of the vulnerable farmers. Data were analyzed and the main themes that emerged were about livelihoods, food security and pandemics of the vulnerable households in developing countries. With the emergence and spread of COVID-19 pandemic the livelihoods in terms of the assets of the farmers in developing countries have been largely altered. Conceptually, the article examined pandemics before coronavirus and their livelihoods implications and effects, followed by a review on coronavirus, livelihoods and its effects on the agricultural dependent farmers and lastly, presented a conclusion and recommendations for development stakeholders especially governments of the developing countries.

\section{Pandemics before COVID-19 and Livelihoods}

Pandemics have long been inflicting humanity and a lot has been written regarding the socio-economic impacts of pandemics (Andayi et al., 2019; Guimbeau et al., 2019; Hintzen, 2019). Worth noting, that health is fundamental to a prosperous productive society, whereas panic and illness can stifle production, consumption, recreation, travel and overall well-being (Marin, 2017; Adeola and Evans, 2018; Lawanson and Evans, 2019; Nwaogwugwu and Evans, 2019; Fourie, 2020). Health disasters such as the Ebola virus in West Africa, the Middle East Respiratory Syndrome (MERS) outbreak in the Republic of Korea and the rise of COVID-19 not only have global health impacts but also wide-ranging socio-economic disruptions and more so on the already vulnerable rural farmers with whom fallback strategies are weak. For example, during the Ebola virus outbreak in West Africa from 2013 to 2014, government revenues declined across the board, including direct taxes on companies, VAT receipts and indirect taxes (Dimmock et al., 2016).

Additionally, with the decline in private and foreign investors' confidence in the economic sector, financing gaps of more than the US\$600 million over the two years of Ebola in West Africa were experienced. These impacts went across many sectors and undoubtedly had long-term consequences in many countries but mostly affected ones were Guinea, Liberia and Sierra Leone (Smith et al., 2019). As if that is not enough, after killing at least 800 people and infecting more than 8000 , the total global economic loss due to SARS was estimated to US\$40 billion. Largely, the fears of the consumers as a result of the transmissibility of the virus in public settings led to all these impacts. Also, the wider economic impact of the 1998 Nipah outbreak in Malaysia was estimated at the US\$582 million (Dimmock et al., 2016).

Currently, as from late 2019 to date, an outbreak of coronavirus disease 2019 (COVID-19)-an infectious disease caused by a newly discovered coronavirus-has been rapidly spreading across the world, devastating lives and livelihoods. This study, therefore, argues that the virus has the potential impacts and related containment efforts on food security and livelihoods in contexts of high vulnerability, especially where populations are already experiencing food crises. This paper argues that the experiences of the vulnerabilities differ across countries due to varying fallback strategies. Therefore, the impacts of COVID-19 in the western world must not be compared to those of Africa because of the varying social and economic dynamics.

Furthermore, (FAO, 2020a) argued that the virus is likely to have significant impacts on food security across the world and such impacts will be more devastating in agricultural highly dependent countries. Drawing and learning from previous crises, particularly from the Ebola virus outbreak in West Africa in 2014, FAO indicated the 
significant impact of movement restrictions and disease containment efforts on food production and access and the importance of maintaining and upscaling humanitarian food security interventions for the most vulnerable populations, alongside the health sector's efforts to avert disease spread. Concerning most developing countries, agriculture is often the lead export sector and foreign exchange earner since it is the sector with a strong comparative advantage in the early stages of development. Even though most African countries have poorly skilled labor which directly suggests a comparative advantage for unprocessed primary products, most of these countries are relatively rich in natural resources. Despite the availability of natural resources, trade restrictions due to COVID-19 is inflicting the livelihoods of the majority population (Byerlee et al., 2009).

In the same fashion, the incidence of COVID-19 has been growing at a disturbing rate with significant impacts on global economies and public health. According to the National Bureau Statistics of China, after a seen 6 percent growth of the last three months of 2019 and when compared with market forecasts of a $6.5 \%$ decline, the (NBSC, 2020) argued that the Chinese economy shrank 6.8 percent year-on-year in the first quarter of 2020. It is the first GDP contraction since records began in 1992, reflecting the severe damage caused by the COVID-19 outbreak after the authorities enforced a near twomonth-long shutdown of all non-essential business activity (Cheng, 2020). The economic contraction of the Chinese economy contracted the majority of her trade partners especially the African continent and this affected the supply of products to and from China. This has immediate impacts being an increase in prices and scarcities of some goods in the markets that have strong trade ties with China.

Largely, this affects the livelihoods of the raw material rich countries and consequently contracting their human development. Economists have further estimated that, without urgent global actions to curtail the virus in time, China is expected to lose up to US \$62 billion in the first quarter of 2020, while the world will lose over the US $\$ 280$ billion. Ayittey et al., (2020) compared these values to the World Bank's estimate that even a weaker flu pandemic, such as the 2009 H1N1 viruses, which still wiped $0.5 \%$ off global GDP, which is approximately US $\$ 300$ billion. Elsewhere, (Cox, 2020) argued that the United States' GDP shrank $4.8 \%$ in the first quarter amid the biggest COVID-19 contraction since the financial crisis.

Emerging from the above, this paper rather indicates the need to learn more from previous pandemics and draw lessons based on their negative implications on food systems in the affected regions. Most importantly, coronavirus is globally and has infected and led to a lot of deaths meaning its implications on food security are enormous. For example, the Ebola pandemic though at a regional level implicated many lives even though food systems were functional in other parts of the world. The 2014 West Africa Ebola Virus Disease (EVD) outbreak had important implications on food security and human development. FAO (2016) showed that the EVD outbreak disrupted the functioning of several cross-border agricultural market chains. This outbreak had a major negative impact on collecting and transporting agricultural production to consumption areas.

This disruption stems from collectors' reluctance to travel to contaminated zones (the number of traders decreased by $20 \%$ at the peak of the outbreak according to WFP) and, to some extent, the transportation difficulties arising from Ebola checkpoints, quarantine zones and the closure of certain borders disrupted the food systems (FAO, 2016). The above impacts on food chains were felt much due to the measures that were put in place in containing the outbreak-in particular the quarantines and restrictions to public gatherings and movements of goods and persons-disrupted agricultural market supply chains and many farmers were unable to grow or sell crops due to lack of inputs and labor as it is the case in the COVID-19 (FAO, 2016). On the aspect of labor, most agricultural activities in Africa demand manual or traditional productive means with less or no machinery at all. Therefore, such restrictions have a lot of impacts negatively on food production and eventually food security. Implications for rural livelihoods implies leads to a lot of effects including more government borrowing and more food importations to meet the demands of food in the local markets.

In this vein, many African governments have found themselves either requesting for debt relief and more borrowing even though the accountability of such debts has remained questionable to a larger extent. Furthermore, the above measures do not only implicate the availability of food in markets but also have extended impacts as they become obstacles that contribute to reduced farmers' incomes (higher costs of inputs and lower negotiating power with collectors whose numbers have decreased) and to the instability of crop prices from geographical and seasonal normal patterns.

Thus establishing an atmosphere of instability and uncertainty for both producers and consumers within these chains is the key to the survival of the poor farmers. Consumer price increases as seen in the Ebola pandemic are also the case now leading to not only limited but also the low purchasing power of an already poor population, which is further weakened by the global economic slowdown (FAO, 2016).

As if that is not enough Ebola in West Africa, considerably impacted food production. For example in Liberia, 47 percent of farmers reported they were unable to cultivate farmland due to the outbreak. Furthermore, 
travel restrictions and suspension of operations of periodic markets disrupted trade flows of food commodities and other necessities. Due to the disruption of markets, in particular international flows due to border controls, there were shortages of goods on the market and this led to an increase in prices of key commodities (UNDG, 2015). In the same manner, COVID-19 has greatly impacted the movements of the people in the process of observing the social distancing and in most developing countries observing social distancing and following all the health regulations is key to their survival as it is not easy to know morbidity (ECDPC, 2020). Morbidity and mortality values may indicate the severity of COVID-19 impact, but may not allow appreciation of the full consequence of impaired productivity from illness for a person, their household and or their community.

Impacts may involve psychological, educational, or professional losses on the individual and household (Evans, 2020). The high death toll during the West Africa Ebola outbreak expanded social and household economic impacts stifled growth rates and lost wages due to inability to work or contagion fear, increased poverty and food insecurity, lost education and lost jobs.

The significance of agricultural productivity growth and market connectivity in poverty reduction cannot be underestimated as it helps in stimulating rural non-farm growth, especially where infrastructural investments are done (Barnes and Binswanger, 1986; Hazell and Haggblade, 1991). For example, in India and Indonesia, growth in rural services was estimated to contribute at least as much as growth in agriculture towards reducing poverty (Byerlee et al., 2009). However, with the coronavirus pandemic, this study argues that the significance of agriculture is being compromised worldwide with people being kept strictly in their houses, with less or no transportation of food in some instances.

It is also worth noting, that the role of agriculture in food security has shifted over time. With rapid population growth and growing food aid in Asia in the 1950 and 1960s and the global food crisis of the mid1970 s, where attention was largely focused on food availability at the global and national levels (Byerlee et al., 2009). The current trends in food go beyond availability to include accessibility, utility and stability of the available food. This paper argues that the latter is more than important in the COVID-19 as it addresses the nutritious aspects which are key in the fight against COVID-19. From the mid-1970s to the 2008 food crisis, the world was generally food secure, producing enough food to meet the dietary needs of today's global population (ADB, 2013). However, the 2008 crisis was a sharp reminder that global food security should not be taken for granted because of uncertainties from growing resource scarcity, rising energy prices, new demands such as biofuels and climate change (Byerlee et al., 2009).

In line with Byerlee and others (2009) this paper argues that without pandemic challenges at the country level, trade can stabilize food availability and prices in countries with rising and diversified foreign exchange earnings-the case for most countries in Asia and Latin America. However, Byerlee and others argued that domestic food availability is still a challenge for many countries in Africa that experience some combination of negative per capita annual growth rates in staple food, large production fluctuations caused by climate variabilities, low foreign exchange earnings and landlocked status or poor infrastructure to import food staples (Byerlee et al., 2009). World price fluctuations place additional strain on import capacity and, therefore, increasing domestic food availability and stability remains essential for development in these countries (Byerlee et al., 2009).

Agriculture plays a crucial role in the economies of developing countries as it provides the main source of food, income and employment to their rural populations (Khanna and Solanki, 2014). According to Khanna and Solanki (2014) and FAO (2000), it has been established that the share of the agricultural population in the total populace is $67 \%$ and that agriculture accounts for $39.4 \%$ of the GDP and $43 \%$ of all exports consist of agricultural goods and (Buiatti et al., 2013), argued that roughly one-quarter of the earth's terrestrial surface is now under cultivation with more land converted to crop production in the past 30 years after 1950 than in the previous 150 years. In many regions-including Europe, North America, Australia and recently Brazil, China and India-humanity have also become skillful at raising yields using inputs like fertilizers, pesticides and organic manures (Buiatti et al., 2013). Therefore, agriculture is and will continue to be critical to the future of many developing countries (DFID, 2014). This may or may not be because agriculture can contribute directly and/or indirectly to economic growth (DFID, 2014), but it will certainly be critical as poverty is still stubbornly predominant a rural phenomenon and this looks set to remain for the next two decades at least. It is in this regard that, this paper argues and states that restrictions put by the public health do have negative impacts on the productive, marketing, processing and transportation of agricultural products from rural areas and vice versa and largely, this is attributed to the fact that African countries having taken western lenses in reducing the spread of COVID-19.

Estimates of global Highly Pathogenic Avian Influenza (HPAI) loss from the outbreaks since 2003 run into billions (FAO, 2006). The cost of the 1997 outbreak in Hong Kong, may have been US\$100s of millions including knock-on effects (FAO, 2006) but the very strict control measures applied may have prevented large scale 
human infection and at the same time increased food insecurities. Despite this, the global poultry sector is dynamic and resilient. Global production and trade had shown the potential to recover quickly from severe outbreaks not until the coming in of the coronavirus which has devastated many people especially the poor farmers with little or no fall back strategies (OECD, 2020).

Historically, the (World Bank, 2006a) in the global development finance report argued that the continued spread of the bird-to-bird version of avian influenza (or bird flu, also known by its scientific identifier H5N1) with limited bird-to-human transmission comprises part of the baseline forecast with huge economic impacts. In this regard, the World Bank in 2006 argued that pandemics can destroy the world's economy. For example, the normal flu with characteristics of transmissibility and deadliness could have serious consequences for the world economy if the world's population had limited immunity.

Estimates suggested that such flu could have infected as much as $35 \%$ of the world's population (WHO, 2006), spreading throughout the world in as few as 180 days. As compared with a normal flu season, where some 0.2-1.5 million people died (WHO, 2003), deaths from even a mild new flu might include an additional 1.4 million people worldwide.

Barry argued that a more virulent form of flu, such as the 1918-9 flu, which was more deadly for healthy adults than normal flu, could have had much more serious consequences, killing as many as 1 in 40 infected individuals (Barry, 2005) or some 71 million, with some authors suggesting that as many as 180-260 million could die in a worst-case scenario (Osterholm, 2005). On the other hand, this paper argues that without the vaccine, the current pandemic has the potential to kill many more people even higher than those from previous pandemics. People are and will keep dying not only due to COVID19 but also from starvation as the pandemic has limited the access and utilization of food especially for countries that were already battling hunger way before COVID-19 due to various reasons which might include climate change for example. World Bank (2006b) showed the impacts of a pandemic globally and how it can affect less developed countries whose population mostly depends on hands mouth survival strategies.

The reports in the table below show the results of three separate simulations of the economic consequences of a pandemic (McKibbin and Sidorenko, 2006). The first and yet mild scenario of a pandemic is drawn and modeled from the Hong Kong flu of 1968-9. Nevertheless, the moderate flu has the characteristics of the 1957 Asian flu; and the severe simulation is benchmarked on the 1918-9 Spanish flu (Burns et al., 2006). It is also worth noting that each of these scenarios of pandemics assumes that efforts in the current pandemic by individuals and official agencies to limit the spread of the disease are no more effectual than those observed during previous epidemics and reflects differences in population density, poverty and the quality of healthcare available. For the world as a whole, a mild pandemic would reduce output by less than $1 \%$ of GDP, a moderate outbreak by more than $2 \%$ and a severe pandemic by almost $5 \%$, constituting a major global recession (McKibbin and Sidorenko, 2006) as shown in Table 1 below. The table below shows how the pandemic of flu affected the world through differing levels of intensity of impacts. Generally speaking, developing countries would be hardest hit, because higher population densities and poverty accentuate the economic impacts in some countries (WHO, 2006).

Drawing from the analysis of the World Bank on the flu pandemic, it shows how a pandemic can negatively implicate world economies, worse off those in less developed countries. Coronavirus has affected the world especially the developed countries and it is highly feared that it will be more severe in less developed countries. FAO (2020a) indicated that while the COVID-19 pandemic is devastating lives, public health systems, livelihoods and economies across the world, populations living in food crisis contexts are particularly exposed to its effects.

Economic analysis to date has focused on the immediate impacts of outbreaks rather than the long term effects of endemic for example avian influenza (FAO, 2006), with smaller but repeated outbreaks over several years (Pfeiffer et al., 2013; McLeod et al., 2008). There has been only limited work on the social and economic impacts of long term control strategies and this is proven by the lack robust policies put in place to have the economies running in an event of an outbreak.

The world is currently inflicted and has been affected especially so in the agriculture sector which in most developing countries is the main source of goods for trading. Therefore, the need to strongly re-examine the social, economic and political strategies meant to reduce the spread of COVID-19 within a context-specific. The paper argues that each country and continent must contextualize the implications of the public health regulations in line with their specific social and economic strengths.

Table 1: Possible economic impacts of the flu pandemic

\begin{tabular}{llll}
\hline (\% change in GDP, first-year) & Mild & Moderate & Severe \\
\hline World & -0.7 & -2.0 & -4.8 \\
High-income & -0.7 & -2.0 & -4.7 \\
Developing & -0.6 & -2.1 & -5.3 \\
East Asia & -0.8 & -3.5 & -8.7 \\
Europe and Central Asia & -2.1 & -4.8 & -9.9 \\
Middle East and North Africa & -0.7 & -2.8 & -7.0 \\
South Asia & -0.6 & -2.1 & -4.9 \\
Deaths (Millions) & 1.4 & 14.2 & 71.1
\end{tabular}

Source: World Bank calculations based on (McKibbin and Sidorenko 2006) 


\section{Coronavirus (COVID-19), Livelihoods and Effects}

In late December 2019, a novel Coronavirus (2019-nCoV) was identified as the cause of a significant number of human cases of respiratory disease in China (Martin, 2020). The current outbreak was first detected in Wuhan City, which is a major domestic and international economic and transport hub in China. In about a month, the deadly virus turned the world upside down and it brought about fear in the people which actually spread faster than the virus itself, which appeared to be highly contagious and now more lethal than its well-known predecessors of the same coronavirus family (Martin, 2020). The UN's Food and Agricultural Organization has stressed the role of trade flows in ensuring food security but failing to address how this can be achieved considering the massive restrictions across every country's bearings on the livelihoods of the people. Despite COVID-19 being global, the solutions in terms of vaccines could be global but public health regulations, especially on possible reduction in the spread of the virus, must be contextualized to a larger extent.

For the EU's interconnected agribusiness model with similar social-economic challenges, trade-in commodities are crucial to the food supply. With regards to agricultural dependent countries, over the past months, instabilities in trade relations in delivering agricultural commodities and farm inputs has been observed, as this is a decisive factor for agricultural production (Lakner, 2020). Furthermore, Lakner (2020) indicated that the observed long queues at border controls affect transportation, especially in the case of fresh produces. The timely delivery of food is imperative for human development. So far in Germany for example, demand has shifted slightly, but delivery is stable for many products. Largely, COVID-19 has seen some resolutions in the European Commission and member states on the issues of over-complex border controls that are now enabling effective and efficient trade flows of agricultural goods and food. It is safe arguing that the complex infrastructure development amongst the EU member countries has played a huge role in the effective facilitation of trade in agricultural products. The opposite is true for the countries in Africa, where hunger levels have been increasing alarmingly since COVID-19.

Therefore, differences in the context of prevailing social and economic dynamics largely demand differences in how COVID-19 must be handled. In the same vein, the rate at which higher-value and more specialized crops face a greater number of hurdles differs due to varying context specificity. These foods-such as some fruits and organic produce grown by smaller-scale farms-generally require more labor (Poppick, 2020) which has been affected due to COVID-19. They are also often sold to restaurants and farmers markets [for example; the
Tuesday market in Zambia-where farmers bring their products for sale] many of which are now widely closed or have reduced service delivery across the country, rather than directly delivering groceries to stores that are still operating. Even if these farmers can continue working on their farms, they may have limited places to sell their goods. In countries like South Africa that experienced total lockdowns, the implications are beyond imagination throwing the majority of the people into poverty.

Aggravated poverty levels largely are exposing many households to a lot of survival strategies due to heightened vulnerabilities. In most cases, this has led to an increase in theft levels, robberies, crime rates and domestic violence. In South Africa for example, Police Minister Bheki Cele recently clarified to the media that the South Africa Police Service had received 2,320 complaints of gender-based violence during just the first week of the lockdown. This is $37 \%$ higher than the weekly average for the 87,290 gender-based violence cases reported during 2019, while the national Gender-Based Violence Command Centre said they have seen triple the usual number of calls on gender based violence (Newham and Du Plessis, 2020). This is not the case with the western world because the population is largely able to continue working from home during the lockdowns due to improved infrastructure development. Unlike, in Africa and most developing countries where lockdowns imply idleness the opposite is being experienced.

Furthermore, Poppick (2020) stated that higher-value goods are also more likely than major staple crops to experience a price spike caused by COVID-19 disruptions and this will bring to light the existence of capitalism which argues for the survival of the fittest. One example comes from apple orchards, which require large crews to plant and prune trees. But many apple growers rely on seasonal workers from outside and many of these workers are struggling to either get visas processed or simply going to the plantation fields due to the restricted movements. Without an adequate workforce, growers may have to leave trees unplanted and branches unpruned. Besides, plantations like the Zambia sugar in Mazabuka District of Zambia, have also faced the challenge of labor as it normally uses the seasonal workers when cutting down sugar cane. Hence, the need for a strong re-examination of such restrictions especially in developing countries where a mere lockdown implies shutting down the operations of companies, industries and agricultural plantations and thereby, aggravating livelihoods of the poor people.

The uncertainties over the Wuhan 2019 Novel Coronavirus (2019-CoV), which has killed at least 457,789 people and infected more than $8,640,618$ as of June 19 and largely interrupted global trade and supply chains, depressing asset prices and forced multinational businesses to make hard decisions with limited information (Worldometer, 2020). In most cases, people 
are in forced lockdowns where the productive sectors are literally on standstill waiting for the end of the virus. The most troubling question is how the world is and will cope up especially when the impacts intensify.

Elsewhere, it is argued that way before COVID-19 hit, 113 million people on the planet were already struggling with severe acute food insecurity due to pre-existing shocks or crises (FAO, 2020b). This means they were already at the end of the hunger spectrum-weak and less well-equipped to fend off the virus (Kymal, 2020). The majority of these people live in rural areas and depend on agricultural production, seasonal jobs in agriculture, fishing, or pastoralism. Therefore, any illness or restrictions on movement or activity, such people will be prevented from working in their land, caring for their animals, going fishing, or accessing markets to sell produce, buy food, or get seeds and supplies. Once public health regulations are imposed on the people especially with the view of reducing the spread of the virus, it then results to negative implications on food systems (FAO, 2020b). These restrictions might be well addressed and handled in a system which is well-functioning with advanced infrastructure development.

Policymakers should take the responsibility of orchestrating trade in crops to avoid trade distrust which results from rigged systems disadvantaging farmers. Lockdowns amongst many restrictions in at least 33 of Africa's 54 countries have blocked farmers from getting food to and from the markets and threatened deliveries of food assistance to rural populations (Mutsaka, 2020). This affects the already inflicted social-economic dynamics in Africa. Also, many informal markets where millions buy their food are shut. Mutsaka indicated that about one in every five people in Africa is food insecure and nearly 250 million, already didn't have enough food before the virus outbreak and that a quarter of the population in sub-Saharan Africa is undernourished (Mutsaka, 2020).

This paper argues that learning from the past and similar Public Health emergencies, restrictions on the movement of goods and people can have significant socio-economic repercussions on people's livelihoods, going beyond the direct impact on health, to affecting the most vulnerable groups. While these restrictions are necessary to limit the spread of a disease, they often lead to disruption of market chains and trade of agricultural products (Jamaica Observer, 2020) with significant potential impacts on the populations that depend on them for their livelihoods, food and nutrition security. The most severe drought in decades is already threatening about 45 million people with hunger across southern Africa (Mutsaka, 2020), where farmers are still recovering from two devastating cyclones that battered Mozambique, Zimbabwe and Malawi last year (Global News, 2020).

Coupled with recent cyclones, climate change has been devastating human development in most Southern
African countries leaving many people food insecure. The paper adds that COVID-19 is simply adding salt to the wounds of hunger, malnutrition and threatened lives and therefore, restrictions must be put to reduce the spread of the virus but at the same time mechanisms and or alternatives of keeping people in employment and ensuring food availability, access, utilization and stability during the pandemic period must be identified. These mechanisms will be fully informed by context-specific research and how best to implement public health regulations while enhancing people's livelihoods.

In such cases, local economies especially in less developed countries are often the hardest hit, as businesses remain shuttered and consumers hunkered down in their homes. Most affected might be mediumsized companies and small businesses as supply chains of their products are disrupted due to restrictions on transportation and people's movements (Deloitte Development LLC, 2020). Even though there have been some interventions in terms of finances at this level, the purchasing power of the masses is still infringed and this still does not solve the problem. The current coronavirus epidemic (Martin, 2020) is also happening in the aftermath of the African Swine Fever (ASF) epidemic that started in August 2018 and affected severely the Chinese pig industry, leading to an increase in prices for consumers and income losses for smallholder farmers.

On the other hand, it can also be argued that farmers in villages might not be immediately hit hard by the virus as they usually keep food in stock but this is only dependent on the harvest and it only stands for those with good harvest (Mason-D'Croz et al., 2020).

It is, however, arguably believed that despite African countries being the net importers of food which continentally amounted to around the US\$65 billion as of 2017, the global trade on which this relies is not expected to be disrupted by the pandemic (UNCTAD, 2018). Unlike in 2007-2008, high energy costs are not pushing up food prices (Moseley, 2020).

Nevertheless, FAO does not agree with this statement and argues that despite this understanding and lack of research showing the impacts of the pandemic on food security the reality will show otherwise as the majority Africans depend on hands mouth which has been affected by the restrictions meant to reduce the spread of the virus. The COVID-19 pandemic is already directly affecting food systems through impacts on food supply and demand and indirectly through decreases in purchasing power, the capacity to produce and distribute food and the intensification of care tasks, all of which will have differentiated impacts and will strongly affect the poor and vulnerable (FAO, 2020b).

Africa also grows much of its supplies. More than $70 \%$ of the population is engaged in agriculture, the majority of which are small-scale farmers. Purely subsistence 
farmers-of whom they are relatively few and by far should be protected as they grow their food (Moseley, 2020). Farmers who produce for the market, as well as their consumption, maybe well-placed to weather crisis too, both in terms of feeding themselves and earning an income when other forms of employment decline. Also, if the age group of 15-44 years, those engaged in the labor force and parents of young children, account for the majority of COVID-19 infections, the impact on economic activity, poverty and food security could be substantial (FAO, 2017). Therefore, income levels are likely to drop significantly during the outbreak, consumption by households could decrease and the prevalence of undernutrition rise.

Economic implications of the COVID-19 can be detrimental not only to public health systems but to trade and travel, food and agriculture industries, various market types and retail chains, among others (FAO, 2017). These sectors are confronted with the threat of the virus wherein consumers are too fearful to access their services because of the supply chain or their workforce is compromised (Evans, 2020). FAO (2011), argued that about $70 \%$ of Africa's food is produced by women and in Southern African countries, for example, rural women are the primary food crop producers while men are more involved in animal husbandry or labor off the farm (Moseley, 2020). Women face several constraints in agriculture besides the current coronavirus which has a higher likelihood of reducing their productivity. Women are also often responsible for the care of children, the sick and the elderly (Moseley, 2020). This means they could have increased exposure to COVID-19 with knock-on implications for food production, food preparation and child nutrition and the ending result will be hunger (Moseley, 2020).

Furthermore FAO (2020b) argued that countries with existing humanitarian crises are particularly exposed to the effects of the pandemic, in terms of both direct impacts on people's health especially, where health systems are already weak, overburdened and malnutrition levels are high and indirect effects such as disruption of livelihoods, food supply chains and access to food, basic services as well as humanitarian assistance. The lessons from the 2014 EVD outbreak in West Africa are clear, while health needs are an urgent and primary concern, we cannot neglect livelihoods and food security-related impacts or we will face deepening humanitarian crises in countries already on the brink (FAO, 2020b).

In other words, while the world prioritizes to support the public health actors' efforts to contain the spread of the disease, the world must also be proactive in anticipating COVID-19 collateral effects by protecting the livelihoods and food access of the most vulnerable people, particularly those in food crisis contexts as such people are considered to have a crisis within a crisis (France 24/7 News, 2020). It is worth noting that food security and health are objectively intertwined. When people's livelihoods and incomes are decimated, they are less able to cope with other shocks, such as extended hospital stays or the death of family members, which leave them even more exposed and vulnerable.

As the access to nutritious food declines, so too will their health, leaving them even more at risk of the worst effects of the disease. Time in memorial, humans have battled emerging diseases through early detection followed by coordinated quarantine, as demonstrated by the SARS outbreak in 2003, the Ebola outbreak in 2014 and the COVID-19 outbreak. Continued and improved coordinated international disease surveillance is important (Evans, 2020). A shift in both research and pandemic management efforts must be geared towards proactive management approaches. In due course, medical science needs an enhanced understanding of the origins of pandemic emergence, spillover and postspillover evolution so that the virus can be better diagnosed and prevented.

\section{Conclusion}

The Coronavirus (COVID-19) outbreak has already brought considerable human suffering and major economic disruptions. The adverse consequences of these developments for other countries are significantly enormous especially in agricultural dependent countries, including the direct disruption to global supply chains, weaker final demand for imported goods and services and the wider regional declines in international tourism and business travel. This study has, however, showed the importance of good health and the need for food security. As long as the coronavirus continues threatening the lives of the people globally, so shall the reduction in food production be strongly affected. The USA for example, one of the economic superpower countries has been largely affected by the virus and the worst has been feared for the developing countries with less or weak fallback strategies and or no capabilities of responding to the effects. This pandemic once again brings the aspect of the survival of the fittest with whom are less concerned about the living standards, it is within this that the role of the state matters a lot. In the name of survival strategies during coronavirus, searching for food and medication, many people especially the vulnerable members of the communities are experiencing the worst of it all, for example in most countries, during COVID-19 rape cases, domestic violence, HIV infections and human trafficking cases are increasing. Largely, COVID-19 has inflicted many lives and hunger levels have been increasing in developing countries. 


\section{Recommendations}

This study recommends for a sustained support and protection of the possible market opportunities for the farmers. In the same vein, due to public health restrictions, small scale farmers must be encouraged to work in cooperatives through which they will be able to sell their farm products to big shopping centers who buy in bulk.

Governments and other development stakeholders must go beyond simply giving financial loans to both Medium and Small Medium Enterprises to set up effective and efficient monitoring and evaluation systems that ensure accountability and transparency of such investments. Functional monitoring and evaluation systems will to some extent enhance transparency, accountability and openness in the utilization of the borrowed funds.

Lastly, the implementation of public health measures in the effort to reduce the spread of the disease must not take the western lens or understanding. Africa for example has context-specific challenges that need to be understood from an African perspective. This requires a good understanding of what these public health measures mean to a vulnerable African agriculture-dependent farmer.

\section{Acknowledgment}

This paper was written by Brivery Siamabele and Yunike Phiri as the authors. But the paper highly acknowledges the contributions made by our colleagues during the development of the manuscript.

\section{Author's Contributions}

All authors equally contributed in this work.

\section{Ethics}

All the sources were acknowledged and well cited in the reference section.

\section{References}

ADB. (2013). Food Security in Asia and the Pacific. Mandaluyong City, Philippines: Asian Development Bank. https://www.adb.org/publications/foodsecurity-asia-and-pacific

Adeola, O., \& Evans, O. (2018). Digital health: ICT and health in Africa. Aktual'ni Problemy Ekonomiky= Actual Problems in Economics, (208), 66-83. https://doi.org/10.1080/02508281.2018.1562662

Andayi, F., Chaves, S. S., \& Widdowson, M. A. (2019). Impact of the 1918 influenza pandemic in coastal Kenya. Tropical Medicine and Infectious Disease, 4(2), 91. https://www.mdpi.com/2414-6366/4/2/91
Ayittey, F. K., Ayittey, M. K., Chiwero, N. B., Kamasah, J. S., \& Dzuvor, C. (2020). Economic impacts of Wuhan 2019-nCoV on China and the world. Journal of Medical Virology, 92(5), 473-475. https://onlinelibrary.wiley.com/doi/abs/10.1002/jmv. 25706

Barnes, D. F., \& Binswanger, H. P. (1986). Impact of rural electrification and infrastructure on agricultural changes, 1966-1980. Economic and Political Weekly, 26-34. https://www.jstor.org/stable/4375175?seq=1

Barry, J. M. (2005). The Great Influenza: The Story of the Deadliest Pandemic in History. London: Penguin Books, ISBN-10: 0143036491.

Buiatti, M., Christou, P., \& Pastore, G. (2013). The application of GMOs in agriculture and in food production for a better nutrition: two different scientific points of view. Genes \& Nutrition, 8(3), 255-270. https://link.springer.com/content/pdf/10.1007/s1226 3-012-0316-4.pdf

Burns, A., Van der Mensbrugghe, D., \& Timmer, H. (2006). Evaluating the economic consequences of avian influenza (p. 6). Washington, DC: World Bank. http://documents1.worldbank.org/curated/en/977141 468158986545/pdf/474170WP0Evalu101PUBLIC1 0Box334133B.pdf

Byerlee, D., De Janvry, A., \& Sadoulet, E. (2009). Agriculture for development: Toward a new paradigm. Annual Review of Resource Economics, 1, 15-31. https://doi.org/10.1146/annurev.resource.050708.14 4239

Cheng, J. (2020). China Records First Ever Contraction in Quarterly GDP on Coronavirus. Wall Street Journal, 17. https://www.wsj.com/articles/china-setto-report-plunge-in-first-quarter-gdp-11587086697

Christiaensen, L. J. (2007). Down to earth: agriculture and poverty reduction in Africa. World Bank Publications. http://hdl.handle.net/10986/6624

Cox, J. (2020). US GDP shrank $4.8 \%$ in the first quarter amid biggest contraction since the financial crisis. CNBC. https://www.cnbc.com/2020/04/29/us-gdpq1-2020-first-reading.html

Deloitte Development LLC. (2020). COVID -19 Managing supply chain risk and disruption. https://www2.deloitte.com/content/dam/Deloitte/ca/ Documents/finance/Supply-hain_POV_EN_FINALAODA.pdf

DFID. (2014). Agriculture and growth Agriculture and growth evidence paper series. Department for International Development June2014. Website: www.gov.uk/dfid

Dimmock, N. J., Easton, A. J., \& Leppard, K. N. (2016). Introduction to modern virology. John Wiley and Sons. https://www.worldcat.org/title/introduction-tomodern-virology/oclc/920469671 
ECDPC. (2020). Considerations relating to social distancing measures in response toCOVID-19second update. Technical Report. European Center for Disease Prevention and Control. https://www.ecdc.europa.eu/sites/default/files/docu ments/covid-19-social-distancing-measures-guidesecond-update.pdf

Evans, O. (2020). Socio-economic impacts of novel coronavirus: The policy solutions. BizEcons Quarterly, 7, 3-12. https://ideas.repec.org/a/ris/buecqu/0013.html

FAO. (2000). The State of Food and Agriculture 2000. Rome. http://www.fao.org/3/x4400e/x4400e.pdf

FAO. (2006). Interim Report on the Global Programme for Control and Eradication of Highly Pathogenic Avian Influenza (HPAI). Emergency Centre for Transboundary Animal Diseases (ECTAD). http://www.fao.org/docs/eims/upload/217280/rep_h pai_sfera_en.pdf

FAO. (2011). The role of women in agriculture: Agricultural Development Economics Division. Viale delle Terme di Caracalla00153 Rome, Italy http://www.fao.org/3/am307e/am307e00.pdf

FAO. (2016). The Impact of Ebola Virus Disease Outbreak on Market Chains and Trade on Agriculture in West Africa. Food and Agriculture Organization of the United Nations. http://www.fao.org/3/a-i5641e.pdf

FAO. (2017). The future of food and agriculture - trends and challenges. Rome. http://www.fao.org/3/a-i6583e.pdf

FAO. (2020a). COVID-19: Our hungriest, most vulnerable communities face a crisis within a crisis. https://www.un.org/africarenewal/news/coronavirus/ covid-19-our-hungriest-most-vulnerablecommunities-face-\%E2\%80\%9C-crisis-withincrisis $\% \mathrm{E} 2 \% 80 \% 9$

FAO. (2020b). Addressing the impacts of COVID-19 in food crises April-December 2020. Rome. http://www.fao.org/policy-support/tools-andpublications/resources-details/en/c/1270454/

Fourie, J. (2020). Beyond 2020: A vision of a prosperous South Africa-economy: Opinion. https://journals.co.za/doi/10.10520/EJC-1a9a2ea00c

France 24/7 News (2020). Crisis within a crisis: Covid-19 exacerbates food insecurity in Africa. EYE on Africa. https://www.npr.org/2020/09/27/913612554/acrisis-within-a-crisis-food-insecurity-and-covid-19

Global News (2020). Coronavirus lockdowns threaten Africa's already. Vulnerable food supply. https://globalnews.ca/news/6820088/coronavirusafrica-aid-food/

Guimbeau, A., Menon, N. and Musacchio, A. (2019). The Brazilian Bombshell? The Long-Term Impact of the 1918 Influenza Pandemic the South American Way. The Long-Term Impact of the 1918 Influenza Pandemic the South American Way. https://www.fea.usp.br/sites/default/files/anexoevento/guimbeau_menon_musacchio.pdf
Hayami, Y., \& Ruttan, V. W. (1971). Agricultural development: an international perspective. Baltimore, Md/London: The Johns Hopkins Press. https://agris.fao.org/agrissearch/search.do?recordID=XL2012002153

Hazell, P., \& Haggblade, S. (1991). Rural-urban growth linkages in India. Indian Journal of Agricultural Economics, 46(4), 515-29. https://ageconsearch.umn.edu/record/272684? ln=en

Hintzen, P. C. (2019). Precarity and the HIV/AIDS pandemic in the Caribbean: Structural stigma, constitutionality, legality in development practice. Global Public Health, 14(11), 1624-1638. https://pubmed.ncbi.nlm.nih.gov/31240999/

Jamaica Observer. (2020). What impact could the coronavirus epidemic have on agriculture and food security?

http://www.jamaicaobserver.com/agriculture/whatimpact-could-the-coronavirus-epidemic-have-onagriculture-and-food-security_189209?profile $=1442$

Johnston, B. F., \& Mellor, J. W. (1961). The role of agriculture in economic development. The American Economic Review, 51(4), 566-593. https://www.jstor.org/stable/1812786?seq=1

Khanna, N., \& Solanki, P. (2014). Role of agriculture in the global economy. In 2nd International Conference on Agricultural \& Horticultural Sciences, Agrotechnology.

https://www.longdom.org/proceedings/role-ofagriculture-in-the-global-economy- 15024.html

Kymal, M. (2020). On The Brink Of Starvation. Best Indian American Magazine. https://indiacurrents.com/on-the-brink-of-tarvation/.

Lakner, S., (2020). Effects of Coronavirus on Agricultural Production. A First Approximation. Brussels. https://www.arc2020.eu/effects-coronavirusagricultural-production.

Lawanson, O., \& Evans, O. (2019). Human Capital, Structural Change and Economic Growth in Developing Countries: The Case of Nigeria. Economics of Human Resource: Issues, Challenges \& Opportunities, A Festschrift in Honour of Professor Folayan Ojo, Lawanson O. I and Nwakeze N. M (Eds.), University of Lagos Press, 89-103. https://ir.unilag.edu.ng/handle/123456789/5499

Marin, B. (2017). Welfare in an Idle Society?: Reinventing Retirement, Work, Wealth, Health and Welfare. Routledge. https://www.taylorfrancis.com/books/mono/10.4324 19781315234229/welfare-idle-society-bernd-marin

Martin, V., (2020). What impact could the coronavirus epidemic have on agriculture and food security? chinadaily.com.cn. https://www.chinadaily.com.cn/a/202002/24/WS5e5 3af6fa310128217279e6d.html 
Mason-D’Croz, D., Bogard, J. R., Herrero, M., Robinson, S., Sulser, T. B., Wiebe, K., ... \& Godfray, H. C. J. (2020). Modelling the global economic consequences of a major African swine fever outbreak in China. Nature Food, 1(4), 221-228. https://www.nature.com/articles/s43016-020-0057-2

McKibbin, W. J., \& Sidorenko, A. (2006). Global macroeconomic consequences of pandemic influenza (p. 79). Sydney, Australia: Lowy Institute for International https://www.brookings.edu/research/globalmacroeconomic-consequences-of-pandemicinfluenza/

McLeod, A., Morgan, N., Prakash, A. and Hinrichs, J. 2005. Economic and social impacts of avian influenza, Rome: FAO Emergency Centre for Transboundary Animal Diseases Operations (ECTAD). http://www.fao.org

Mellor, J. W. (1998). Agriculture on the Road to Industrialization. International agricultural development, $136-154$ https://thedocs.worldbank.org/en/doc/237161485893 105277 -

0050022017/render/GFR22501KCPIIIRegulationan dRuralTransformation.txt

Moseley, W., (2020). How will COVID-19 affect Africa's food systems? Food supplies shouldn't be too badly affected, but social restrictions will make it hard for many to buy and access food.https://africanarguments.org/2020/03/25/covid19-africa-food-systems.

Mutsaka, F. (2020). Virus choking off supply of what Africa needs most. Food. https://sunny95.com/news/030030-virus-chokingoff-supply-of-what-africa-needs-most-

NBSC. (2020). Trading Economics. China GDP Annual Growth Rate 1989.2020 Data 2021-2022 Forecast National Bureau of Statistics of China. http://ghdx.healthdata.org/organizations/nationalbureau-statistics-china

Newham, G., \& Du Plessis, A. (2020). How might the COVID-19 lockdown affect public safety in SA? Institute for Security Studies. https://issafrica.org/isstoday/how-might-the-covid-19-lockdown-affectpublic-safety-in-sa

Nwaogwugwu, C. I., \& Evans, O. (2019). What are the Short-run and Long-run Drivers of Human Capital Development in Nigeria? In Lawanson O. I \& Nwakeze N. M (Eds.), Economics of Human Resource: Issues, Challenges \& Opportunities. A Festschrift in Honour of Professor Folayan Ojo, (pp. 263-284), University of Lagos Press. https://mpra.ub.unimuenchen.de/97130/3/MPRA_paper_97130.pdf
OECD. (2020). Coronavirus: The world economy at risk. https://www.oecd.org/berlin/publikationen/InterimEconomic

Osterholm, M. T. (2005). Preparing for the next pandemic. New England Journal of Medicine, 352(18), 1839-1842. https://www.nejm.org/doi/full/10.1056/nejmp058068

Pfeiffer, D. U., Otte, M. J., Roland-Holst, D., \& Zilberman, D. (2013). A one health perspective on HPAI H5N1 in the Greater Mekong sub-region. Comparative Immunology, Microbiology and Infectious Diseases, 36(3), 309-319. https://doi.org/10.1016/j.cimid.2012.11.005

Poppick, L. (2020). The effects of COVID-19 will ripple through food systems. Scientific American.

Schultz, T. W. (1964). Transforming traditional agriculture. Transforming traditional agriculture. https://www.cabdirect.org/cabdirect/abstract/19641802 933

Smith, K. M., Machalaba, C. C., Seifman, R., Feferholtz, Y., \& Karesh, W. B. (2019). Infectious disease and economics: The case for considering multi-sectoral impacts. One Health, 7, 100080. https://doi.org/10.1016/j.onehlt.2018.100080

Thirtle, C., Lin, L., \& Piesse, J. (2003). The impact of research-led agricultural productivity growth on poverty reduction in Africa, Asia and Latin America. World Development, 31(12), 1959-1975. https://www.sciencedirect.com/science/article/abs /pii/S0305750X03001682

Timmer, C. P. (2002). Agriculture and economic development. In: B. L. Gardner \& G. C. Rausser (ed.), Handbook of Agricultural Economics, (pp. 1487-1546), https://ideas.repec.org/h/eee/hagchp/3-29.html

UNCTAD. (2018). Key Statistics and Trends in International Trade. United Nations Conference on Trade and Development, United Nations, Geneva. https://ageconsearch.umn.edu/record/267635

UNDG. (2015). Socio-economic impact of Ebola virus disease in West African countries: A call for national and regional containment, recovery and prevention. United Nations Development Group. -Western and Central Africa. https://www.cdc.gov/vhf/ebola/history/2014-2016outbreak/cost-of-ebola.html

WHO. (2003). The world health report 2003: shaping the future. World Health Organization. ISBN-10: 9241562439.

WHO. (2006). Avian Influenza ("bird flu") Fact Sheet. World Health Organization. http://www.who.int/mediacentre/factsheets/fs211/en /index.html 
Brivery Siamabele and Yunike Phiri / American Journal of Agricultural and Biological Sciences 2021, Volume 16: 38.49 DOI: 10.3844/ajabssp.2021.38.49

World Bank. (2006a). Disease Control Priorities in Developing Countries. 2nd edition. https://doi.org/10.1596/978-0-8213-6179-5

World Bank. (2006b). Global development finance: The development potential of surging capital flows. https://openknowledge.worldbank.org/handle/10986 /8125 License: CC BY 3.0 IGO.”
Worldometer.

(2020).

Coronavirus.

https://www.worldometers.info/coronavirus/ 